\title{
THE SPREAD OF EBOLA
}

\section{HOW THE WORLD HEALTH ORGANIZATION'S RHETORIC CONTRIBUTED TO VIRUS TRANSMISSION}

Celeste Condit

The tragedy of the 2014 Ebola epidemic in West Africa was exacerbated by World Health Organization (WHO) rhetoric that depicted medical personnel as saviors of an irrational and emotional public. That common rhetoric rests on a faulty image of scientific knowledge as a substance that binds its affiliates into a community with special powers and immunities. This analysis shows how such rhetoric blinded the international community to attending to the potential role of health care sites and health care workers as vectors of disease transmission. This case illustrates why analysis of rhetoric is part of a full scientific approach to gaining, sharing, and deploying knowledge.

Keywords: Ebola, rhetoric of science, health communication, science communication, World Health Organization.

By the end of October 2014, over 500 health care workers had contracted Ebola in West Africa; over half had died. Rhetoric did not kill these people; Ebolavirus did. Nonetheless, a specific rhetoric employed by the World Health Organization (WHO) impeded the containment of the epidemic because it coded medical personnel as expert saviors rather than as vectors of the disease. This tragic instance reveals yet again that understanding the rhetoric used by health care officials is, in crucial ways, as important to controlling epidemics as is understanding the virus itself.

To analyze the rhetorical dimensions of any human discourse requires attending closely to how the particular structuration of that discourse encourages different audiences to envision their relationships with others, and therefore to take some actions, rather than others. All complex language use inevitably includes rhetorical dimensions, and recently many scholars have in particular begun to analyze the metaphoric and narrative dimensions of health discourses, including those of epidemics such as flu, Ebola, and HIV (Leach, Scoones, \& Sterling, 2010; Wallis \& Nerlich, 2005).
If one wishes to cut short similar events in the future, the present analysis indicates, health officials should avoid the temptations of common rhetoric that vividly depicts medical personnel as saviors of an irrational, ignorant, and emotional public. Such rhetoric is based on a faulty implicit vision of scientific knowledge as a substance that binds its affiliates into a community with special powers and immunities. To demonstrate that claim and point toward more therapeutic ways of talking, this essay examines WHO's rhetoric about health care workers and Ebola up to mid-October 2014. All discourse posted on WHO's Ebola webpages during that period was included in the analysis, which identified the ways in which these texts portrayed the relationships among health care workers, the public, and the virus. The goal of such an analysis is not to condemn the shortcomings of the WHO, an underfunded organization that is hampered by international conditions, but rather to participate in the continual process of improving our health practices. 


\section{THE CLUE THE WHO'S RHETORIC AVOIDED}

Throughout the first months of this outbreak, the evidence clearly indicated that medical personnel and facilities were important nodes in the spread of Ebola. Yet health care workers were given special exemptions in surveillance procedures, their role as vectors was papered over by scientific literature, and they were depicted by WHO's public rhetoric as victims of an irrational public. There is ample evidence for each arm of this incongruity.

\section{Medical personnel spread ebola}

The evidence of the role of health care workers and health care sites in Ebola's spread was available from previous outbreaks. A publication sponsored by the U.S. Centers for Disease Control (CDC) had noted in June: «health-care-associated transmission has played a part in transmission during previous outbreaks» (Dixon \& Schafer, 2014, p. 548; Fasina, 2014, p. 6). By October, WHO (World Health Organization, 2014a) conceded that $8 \%$ of those who had contracted the disease in the present outbreak were health care workers. Such admissions focused on the harm to the caregivers and the problems this caused in maintaining a sufficient supply of medical personnel. They did not typically take up the question of whether health care workers and health care sites were themselves problematic sources of infection. Damning evidence was ready to hand.

Wide-ranging testimony indicated that the precautions taken in most health care sites were inadequate to protect health care workers and their patients because of the stark difficulties of maintaining absolute protection in minimalist conditions (Fink, 2014). Health care workers also moved between Ebola units and other wards to treat other patients, some of whom created exposure risks because they had undiagnosed Ebola. The numbers of contacts of infected health care workers were potentially staggering. One health care worker in Nigeria was traced to 526 different contacts (Fasina, 2014, p. 1). Meanwhile, people being tested for Ebola were kept at health care sites for as long as two days in areas that were neither Ebola-free nor maintained with the rigorous disinfection and other protocols of areas for confirmed Ebola patients. If you were one of the lucky ones whose test showed your original symptoms were not produced by Ebola, you might contract it during a stay in such a diagnostic unit (WHO, 2014b). If you were hospitalized with Ebola, you probably died there.

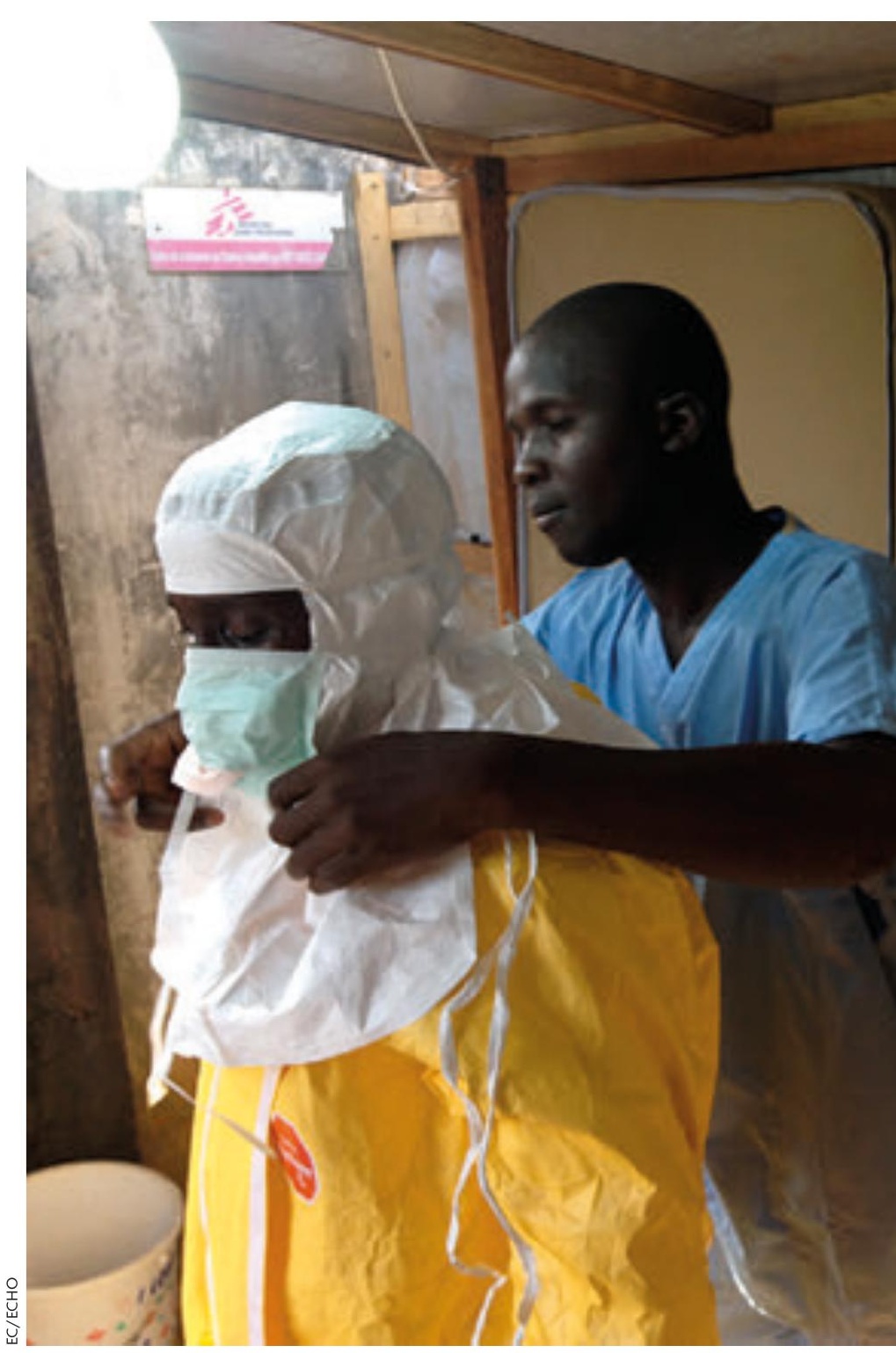

By the end of October 2014, over 500 health care workers had contracted Ebola in West Africa. In the picture, health care workers wearing protective clothing in Guinea.

"THE GOAL OF THE ANALYSIS IS NOT TO CONDEMN THE SHORTCOMINGS OF THE WHO, AN UNDERFUNDED ORGANIZATION HAMPERED BY INTERNATIONAL CONDITIONS" 


\section{MONOGRAPH}

Word of science

they transmitted the disease at a rate below the critical threshold for containing the epidemic. Metzer et al. (2014, p. 3) indicated that «the average daily risk for transmission is greater than zero in these facilities (i.e., transmission does occur), but the risk is fewer than one person infected per infectious patient».

The medical establishment presumed themselves to be saviors rather than vectors using the logic of public health. In contrast, the general populace used their own reasonable dictum - avoid contact with obvious sources of transmission. Members of the general populace recognized that health care workers and health care sites were potential transmitters of the disease. Moreover, they did not see a substantially better chance of surviving Ebola in the often rudimentary health care sites, about which WHO (2014e, p. 11) itself said, «It's not a huge survival benefit.» So members of the public were acting reasonably when they sought to avoid these infected locations. Using this logic, they also sometimes gathered to act forcefully to exclude these vectors from their communities.

\section{"THE EVIDENCE OF THE ROLE OF HEALTH CARE WORKERS AND HEALTH CARE SITES IN EBOLA'S SPREAD WAS AVAILABLE FROM PREVIOUS OUTBREAKS"}

\section{WHO 'vs.' public's health logic}

WHO and officials from other medical organizations represented these reasonable behaviors as irrational, even panicked, outbursts. For example, one WHO report lamented:

Last week, health workers in several parts of the country were viciously attacked by angry mobs, forcing some medical teams to flee for their lives. One team hid in the bush for more than a day. Others saw their vehicles vandalized and their medicines and equipment collected and publicly burned, as though such acts might work as a «cleansing» ritual».

(WHO, 2014f)

Six months after the outbreak, an embattled WHO Director-General, Dr. Margaret Chan (WHO, 2014g), similarly depicted the irrational public as an obstacle to the efforts of the knowledgeable health care officials: «rumours and panic are spreading faster than the virus. And this costs money. Ebola sparks nearly universal fear. Fear vastly amplifies social disruption».

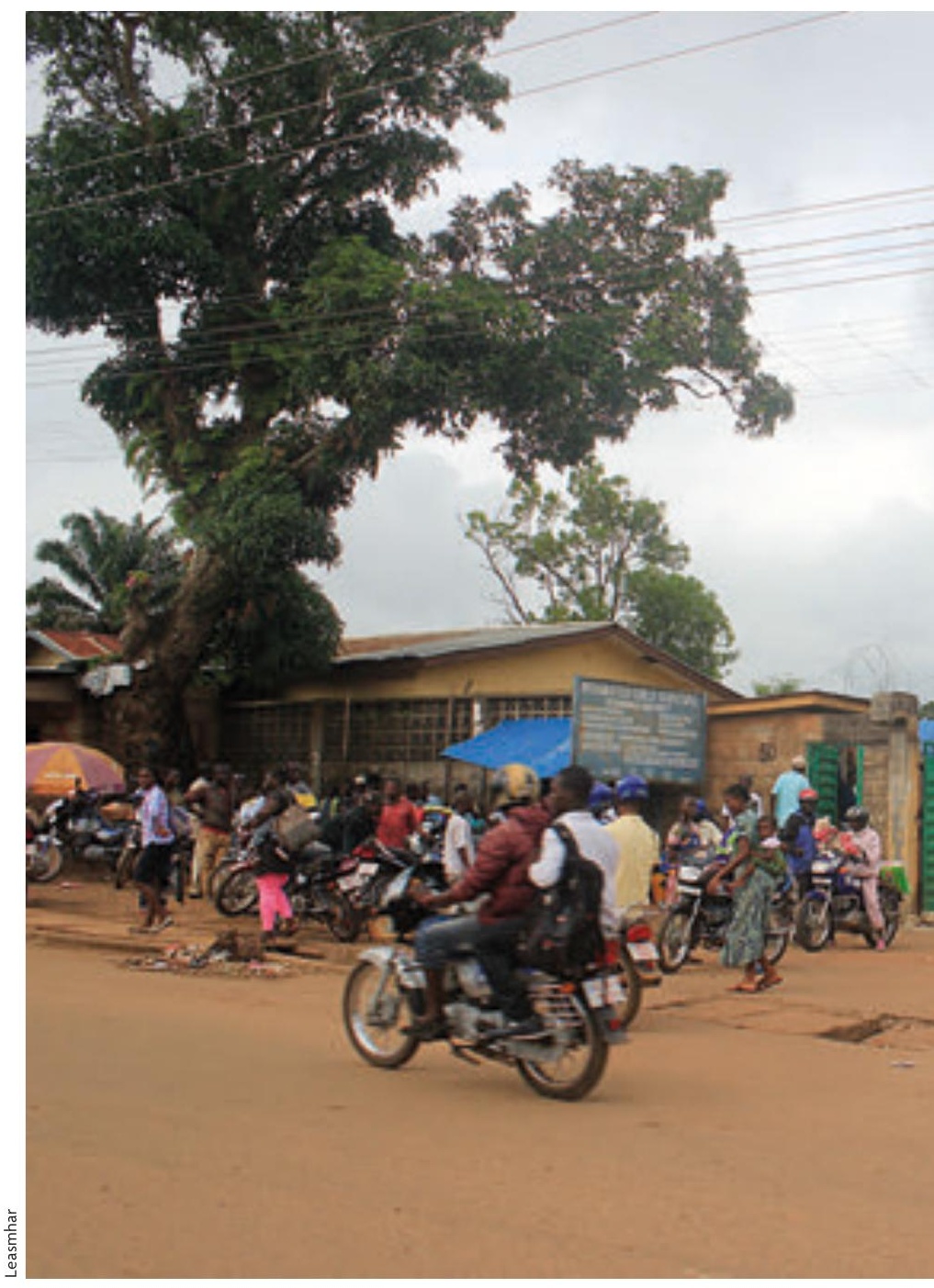

In spite of this evidence, WHO statements and recommendations until October ran counter to the guidance from manuals developed from previous epidemics that had emphasized the special vulnerability of health care workers and health care sites. Above, picture of the Kenema health centre in Sierra Leone, one of the areas affected by the Ebola outbreak.

"WIDE-RANGING TESTIMONY INDICATED THAT THE PRECAUTIONS TAKEN IN MOST HEALTH CARE SITES WERE INADEQUATE TO PROTECT HEALTH CARE WORKERS AND THEIR PATIENTS» 


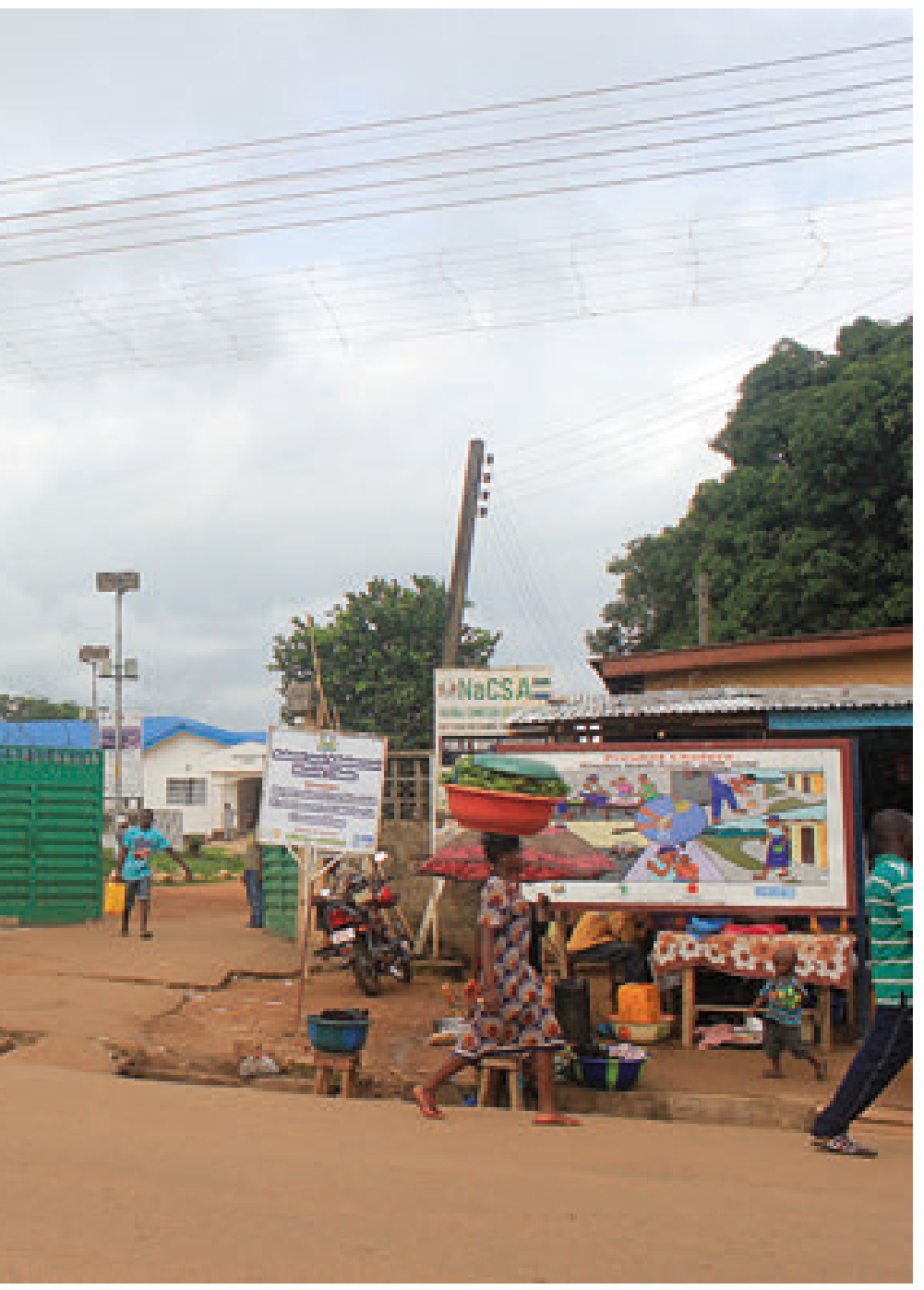

with other «suspect» patients who may infect you. Attending such centers might serve the rational public goal of controlling the epidemic - even with imperfect infection controls - but a reluctance to offer yourself as a personal sacrifice for that larger goal is not irrational. Medical knowledge about Ebola did not confer immunity from Ebola on health care workers, and that knowledge became threatening when health care officials sought to use it to justify control of others against their personal interests.

\section{WHY COULD WHO NOT SEE HEALTH CARE WORKERS AS VECTORS?}

There are multiple reasons why WHO might dodge the role of health care sites and health care workers as vectors of the infection. The practical difficulties of treating all medical personnel involved as «suspect» are obvious, proper controls would make it harder to recruit health care workers, and the public image problems have been admitted (Forrester et al., 2014, p. 927). But if medical personnel are indeed vectors, then such practical difficulties cannot trump the facts if one is to stop the spread of the disease «while minimizing the risks to individuals».

The breadth of this rhetorical failing extends beyond Ebola. My previous analysis of WHO's treatment of the «Super-flu» also showed this tendency to depict scientists as anointed by «truth», which granted them the power to decide in place of the emotional public. That was why I began this research, with the prediction that rhetoric would blind WHO to its own limitations, and the data constituted by their statements confirm that concern.

These portraits, which contrasted the knowledgebearing agents of medical science with the emotional populace, were motivated by a variety of factors: status drives, appreciation for hard-won knowledge, as well as sadness at the ongoing tragedy. But they are deeply wrong; fear of Ebola is not irrational. It is not irrational to fear that you will get Ebola from a physician who is dealing with dozens of tragically ill patients night and day. It is not irrational to oppose a truckful of strangers with space suits invading your village and dragging away your loved ones to die. It is not irrational to avoid a triage center where you will be confined for two days
«THE MEDICAL ESTABLISHMENT PRESUMED THEMSELVES TO BE SAVIORS RATHER THAN VECTORS USING THE LOGIC OF PUBLIC HEALTH»
Rhetorical analysis can thus be predictive. Which is to say, it is well past time that scientists expand their understanding of what «doing science» demands: achieving maximal «objectivity» requires incorporating an understanding of rhetoric into science rather than setting science up as the opponent of rhetoric.

\section{The facts to which science has been blind}

Promoters of science tend to deny or overlook the dependence of science on symbol systems. But if symbol systems are a crucial component of science, then analyzing one's words must form a crucial part of an ideal scientific method. Science 
is not the opposite of argument. There has never been and cannot be any science without verbal argument. The complexities of the natural world and humanity's glorious capacities for sophisticated symbolic systems mean that experiments are crucial to correcting arguments, but not sufficient for making them. The methods of rigorous observation, quantification and experimentation indeed add something important to older techne of argument, but they cannot remove the role of argument in the pursuit of truths. This is even more obvious when we move from bench science to solving the important challenges of our world.

To some extent, $\mathrm{WHO}$ has recognized the importance of language. They imported cultural experts to try to translate «their» language into public actions. In October 2014, they began to tout the successes of those who employed a communityoriented approach to containing the Ebola epidemic (WHO, 2014h) and to concede the substantial role played by the general public in getting the epidemic under control (WHO, 2014e, p. 4, 7). By November,

«IT IS NOT IRRATIONAL TO FEAR THAT YOU WILL GET EBOLA FROM A PHYSICIAN WHO IS DEALING WITH DOZENS OF TRAGICALLY ILL PATIENTS NIGHT AND DAY»

glimmers of a change also appeared in their rhetoric about transmission. Though they did not explicitly admit that health care workers and health care sites were vectors, they began to systematically chart health care workers' cases in situation reports. Tellingly, in the November 5 report (WHO, 2014i), the gradually expanding section referring to the infection of health care workers changed from its focus being solely on the well-being of health care workers («to ensure that all health care workers are exposed to the minimum possible level of risk», e.g. in October 29 [WHO, 2014e, p. 6]) to recognizing the role of health care workers' infections in patient risk («for the protection of health care workers and patients» [WHO, 2014i, p. 4]).

These reflections, however, need to go deeper. The health care establishment should not have been slower to learn this than the general public. And the fundamental rhetorical error will spawn new errors in different contexts if the underlying principle is

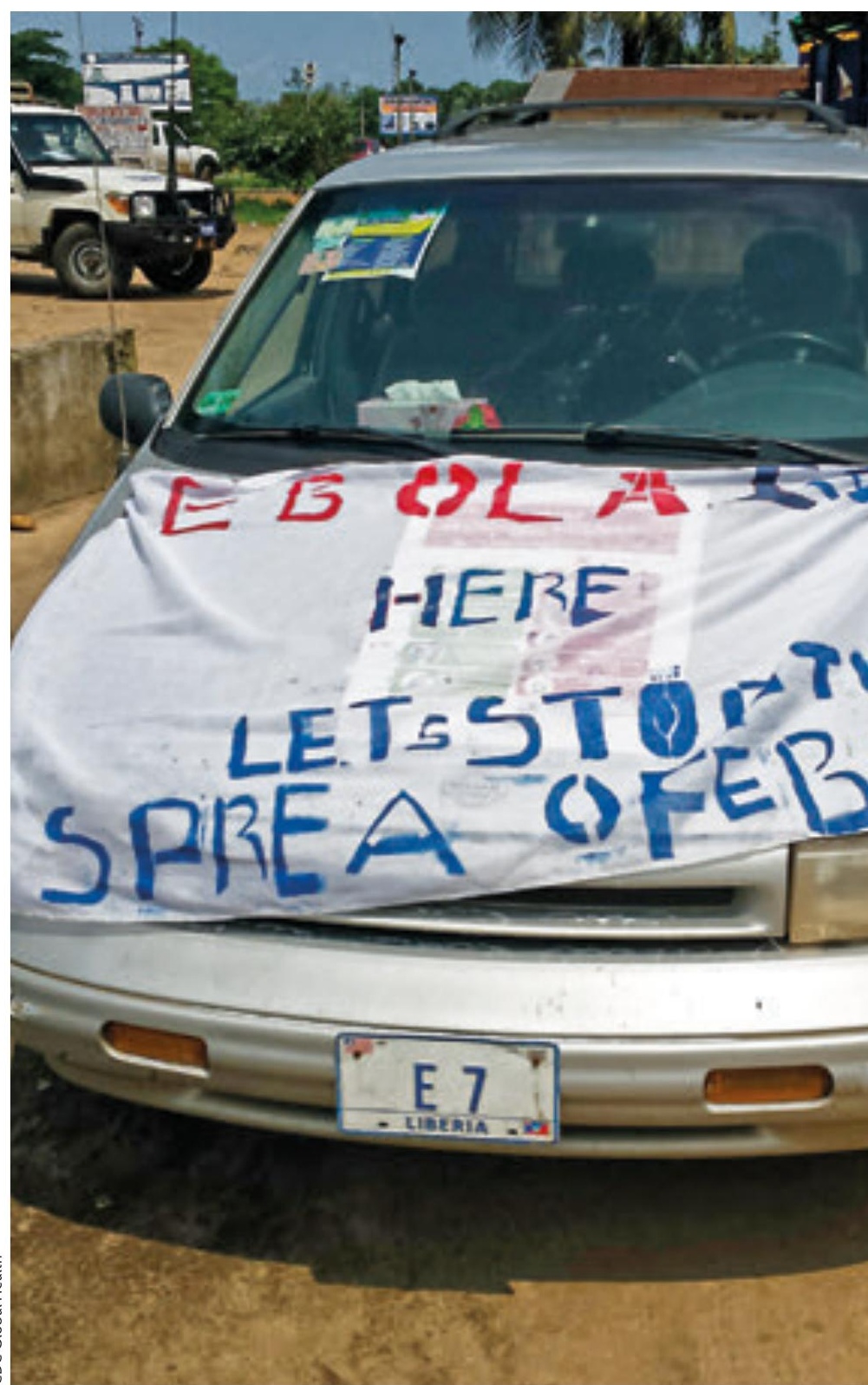

To some extent, WHO has recognized the importance of language. They imported cultural experts to try to translate «their» language into public actions. In the photograph, a car in Monrovia, Liberia, with the following message: «Ebola is here. Let's stop the spread of Ebola.»

«AN APPROACH THAT RESPECTS EVERYONE'S KNOWLEDGE AND INTERESTS WOULD HAVE PAY-OFFS, EVEN FROM THE PERSPECTIVES OF THE HEALTH CARE ESTABLISHMENT» 
not learned. In addition to using care in translating their knowledge into other idioms, health officials need to reflect on their language about themselves. Scientific knowledge is not a magic bullet that grants special powers and immunities to the humans that possess it. As research studies have repeatedly shown, the public has different sorts of applied knowledge that must be respected and brought to bear, not dismissed as irrational or emotional, if sustained actions based on fullest understandings are sought (Wynne, 2006).

An approach that respects everyone's knowledge and interests would have pay-offs, even from the perspectives of the health care establishment. WHO, the CDC, the NIH (National Institutes of Health) and others have emphasized the need for more personnel. They have recognized the need for more hands, eyes, and ears to do many jobs. By setting themselves up as uniquely empowered experts who should control and direct the irrational public, health care organizations cut themselves off from the reservoirs of those eyes, ears, and hands, as well as from additional ideas and imagination. I have previously suggested ways in which WHO could use the internet to incorporate multidisciplinary and multinational insights to augment health care policy development (Condit, 2014). Other existing models (WHO, 2014h) could be expanded and additional possibilities developed to augment epidemic control once health care experts adopt a more self-aware stance about their self-depictions. A more therapeutic rhetoric would depict all of us as a little bit rational, a little bit emotional, and having a little bit of knowledge - but not enough. ()

\section{REFERENCES}

Condit, C. M. (2014). Insufficient fear of the "super-flu"? The World Health Organization's global decision-making for health. Poroi, 10(1). doi: 10.13008/2151-2957.1149

Dixon, M. G., \& Schafer, I. J. (2014). Ebola viral disease outbreak - West Africa, 2014. Morbidity and Mortality Weekly Report, 63(25), 548551. Retrieved from http://www.cdc.gov/mmwr/preview/mmwrhtml/ $\mathrm{mm} 6325 \mathrm{a} 4 . \mathrm{htm}$

Fasina, F. O. (2014). Transmission dynamics and control of Ebola virus disease outbreak in Nigeria, July to September 2014. Euro Surveillance, 19(40), pii=20920. Retrieved from http://www.eurosurveillance.org/ ViewArticle.aspx?ArticleId=20920

Fink, S. (2014, 16 October). In layers of gear, offering healing hand to Ebola patients in Liberia. The New York Times. Retrieved from http://nyti. $\mathrm{ms} / 1 \mathrm{rh} 6 \mathrm{o} 07$
Fitzpatrick, G., Vogt, F., Moi Gbabai, O. B., Black, B., Santantonio, M., Folkesson, E., ... Van Herp, M. (2014). Describing readmissions to an Ebola Case Management Centre (CMC), Sierra Leone, 2014. Euro Surveillance, 19(40), pii=20924. Retrieved from http://www. eurosurveillance. org $/$ ViewArticle.aspx?ArticleId=20924

Forrester, J. D., Hunter, J. C., Pillai, S. K., Arwady, A., Ayscue, P., Matanock, A., ... De Cock, K. M. (2014). Cluster of Ebola cases among Liberian and U.S. health care workers in an Ebola treatment unit and adjacent hospital - Liberia, 2014. Morbidity and Mortality Weekly Report, 63(41), 925-29. Retrieved from http://www.cdc.gov/mmwr/ preview $/ \mathrm{mmwrhtml} / \mathrm{mm} 6341 \mathrm{a} 3 . h t m ?$ s_cid=mm6341a3_w

Leach, M., Scoones, I., \& Sterling, A. (2010). Governing epidemics in an age of complexity: Narratives, politics, and pathways to sustainability. Global Environmental Change, 20, 369-377. doi: 10.1016/j. gloenvcha.2009.11.008

Meltzer, M. I., Atkins, C. Y., Santibanez, S., Knust, B., Petersen, B. W., Ervin, E. D., .. Washington, M. L. (2014). Estimating the future number of cases in the Ebola epidemic - Liberia and Sierra Leone, 2014-2015. Morbidity and Mortality Weekly Report, 63(03), 1-14. Retrieved from http:// www.cdc.gov/mmwr/preview/mmwrhtml/ su6303a1.htm?s_cid=su6303a1_w

Wallis, P., \& Nerlich, B. (2005). Disease metaphors in new epidemics: The UK media framing of the 2003 SARS Epidemic. Social Science \& Medicine, 60(11), 2629-2639. doi: 10.1016/j.socscimed.2004.11.031

World Health Organization. (2014a). A

fast-moving Ebola epidemic full of tragic surprises. Geneva, Switzerland. Retrieved from http://www.who.int/csr/disease/ebola/ ebola-6-months/surprises/en

World Health Organization. (2014b). Urgently needed: Rapid, sensitive, safe and simple Ebola diagnostic tests. Geneva, Switzerland. Retrieved from http://www.who.int/mediacentre/news/ebola/18-november-2014diagnostics/en

World Health Organization. (2014c). Travel and transport risk assessment: Interim guidance for public health authorities and the transport sector. Geneva, Switzerland. Retrieved from http://www.who.int/csr/resources/ publications/ebola/travel-guidance/en

World Health Organization. (2014d). Ebola response roadmap situation report. Geneva, Switzerland. Retrieved from http://apps.who.int/iris/ bitstream/10665/137424/1/roadmapsitrep_31Oct2014_eng.pdf?ua=1

World Health Organization. (2014e). WHO virtual press conference on Ebola response. Geneva, Switzerland. Retrieved from http://www.who.int/ mediacentre/multimedia/vpc-29-october-2014.pdf

World Health Organization. (2014f). Ground zero in Guinea: The Ebola outbreak smoulders - undetected - for more than 3 months. Geneva, Switzerland. Retrieved from http://www.who.int/csr/disease/ebola/ebola6-months/guinea/en

World Health Organization. (2014g). What this - the largest Ebola outbreak in history - tells the world. Geneva, Switzerland. Retrieved from http:// www.who.int/csr/disease/ebola/ebola-6-months/lessons/en

World Health Organization. (2014h). Liberia: Working with communities is the key to stopping Ebola. Geneva, Switzerland. Retrieved from http:// www.who.int/features/2014/liberia-stopping-ebola/en

World Health Organization. (2014i). Ebola response roadmap situation report. 5 November. Geneva, Switzerland. Retrieved from http://apps.who. int/iris/bitstream/10665/137510/1/roadmapsitrep_5Nov14_eng.pdf Wynne, B. (2006). Public engagement as a means of restoring trust in science? Hitting the notes, but missing the music. Community Genetics, 9, 211-220. doi: 10.1159/000092659

Celeste Condit. PhD, University of Iowa. Distinguished Research Professor in the Department of Communication Studies at the University of Georgia (USA). She currently focuses on the role of emotion in public discourse especially at the global level. She has served as co-editor of Women's Studies in Communication and Critical Studies in Media Communication (both with Bonnie J. Dow). 